learns about the matching process, making it more efficient and generalizable. Watson may also help locate patients for hard-to-fill trials, such as those involving rare diseases.

In late October, IBM Watson disclosed results of a year-long project with the Cleveland Clinic in Ohio to help improve the interaction between physicians, data and medical records, and speed decision making. It has also announced a joint effort with Pathway Genomics to commercialize a direct-to-consumer, genetic test-based mobile application (Box 1). Watson is also selling its Watson Discovery Advisor software kit to companies and institutions including New Brunswick, New Jerseybased Johnson \& Johnson and the Baylor College of Medicine in Houston, to improve drug discovery. It is also supplying Sanofi, in
Paris, with the Watson technology for drug repurposing. Of the 3,700 companies that have approached IBM Watson to ask about building on top of its technology, 30\% are from the healthcare field, encompassing services for patient care from personal wellness to understanding drug-drug interactions to help in selection and analysis of clinical trials.

Mark Ratner Boca Raton, Florida

\title{
How frothy is this IPO window?
}

Kurmann Partners, of Basel, have analyzed the performance of biotechs that had their initial public offering (IPO) over the past 15 years. Firms that went public during the 2000/2001 bubble haven't fared well; those that survived the burst bubble recovered enough value to post modest gains, but the legions that went bankrupt or were bought in a trade sale for lower than their offering price wiped out all those gains.

From 2010 to 2012 (the post-Lehman period), companies have almost doubled their value on average, mostly from share price appreciation. Since that time, IPO activity has also increased substantially, but those firms that have gone public are clustered around the $1 \times$ mark because there hasn't been much time to see an increase in share price.

Although a repeat of the post-millennium downturn is possible, Joe Panetta, president and CEO of San Diego's Biocom, thinks this IPO window is different. He says, "Some of the guesswork has been taken out of biotechnology, and I think maybe that's contributed to the IPO market remaining resilient for a couple of years." This time, companies' shares have not, on the whole, increased dramatically after their IPO and investors are still being selective, a sign that the biotech market isn't too overheated. "There are deals that don't get done," adds Jason Forschler executive director in Healthcare Investment Banking at
J.P. Morgan in San Francisco. Those whose share price increased beyond the offering price are usually sought-after companies with oversubscribed IPOs, which require investors wanting to buy additional shares to do so on the open market.

Company valuations have changed, too. During the 2000 bubble, companies with little to no revenue were valued as much as small pharmaceutical companies. "We're just not seeing across-the-board outrageous valuations," says Jay Lichter managing director of La Jolla, California-basead Avalon Ventures. "It's very different today," Forschler agrees. "On average, companies going public are more mature than in 2000. We don't view it as a window. We hope it's here to stay."

If the IPO boom continues, capital should ultimately flow back into early-stage venture funds as equity investors in these enterprises sell their shares on the open market. In practice, IPOs generally aren't a rapid exit event for current shareholders because many new biotechs have limited liquidity. Even if a downturn were to happen, it would have little effect on private investors for most university spinouts. "I don't think it's wise to base early-stage investment decisions purely on the markets of today. We need to plan for several cycles into the future," says Bruce Booth, partner at Atlas Venture, of Cambridge, Massachusetts.

Brian Orelli San Diego, California
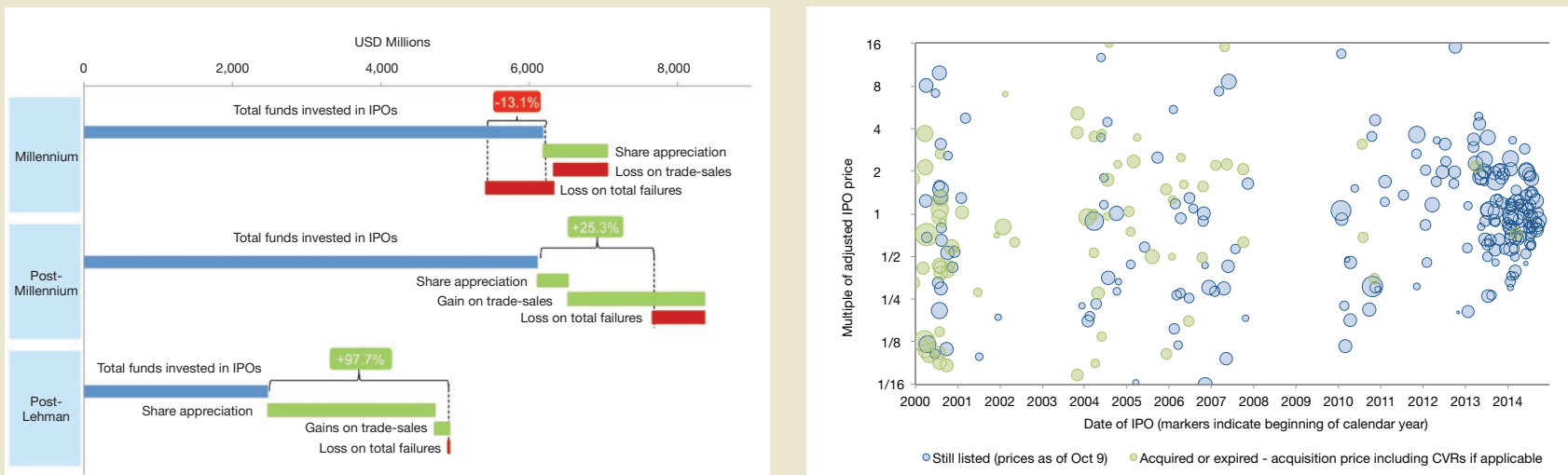

Performance of companies on the public markets. Left panel: amount raised versus gain or loss (as of October 2014) following IPO for firms in the 2000 genomics bubble (Millennium), 2000-2008 (Post-Millennium) and post-2008 (Post-Lehman) periods. Right panel: stock performance of individual IPOs. Bubble area indicates size of IPO. Data compiled by Kurmann Partners IMAP Switzerland (http://www.kurmannpartners.com/) for publication in Boston Biotech Watch (http://www. Bostonbiotechwatch.com/). CVR, contingent value right. 